\title{
Studies on Search for a Promising Immunopotentiative Substance for Treatment of Leprosy
}

\author{
( I) Analytical Studies on Bamboo Grass
}

\author{
MASAICHI GIDOH, SADAE TSUTSUMI (National Institute for Leprosy Research) \\ SHINJI KANIWA (National Saitama Hospital) \\ MINORU NARITA (National Leprosarium, Tama Zensho-en) \\ JITSUNOSUKE MATSUMURA (Bethlehem Hospital) \\ SHOJI TAKITANI (Science University of Tokyo) \\ KATSUNARI FUKUSHI (Nihon Medical College)
}

(Received for Publication, July 17, 1979)

As reported on the precedent paper ${ }^{1 /}$, the immunopotentiation therapy combined with chemotherapy was supposed to be a suitable means for the treatment of leprosy. On the other side, according to a recent report by Birdi, et $a l .{ }^{2}$, not only viable but even heatkilled leprosy bacilli inhibited the uptake of ${ }^{3} \mathrm{H}$-leucine by mouse and human macrophages. This result suggests us a possible injurious action of leprosy bacilli on protein synthesis inside macrophages and even a possible presence of an in vitro stable injurious substance to macrophages in leprosy bacilli. It also suggests us an immunodepressive action by leprosy bacilli themselves on $T$ cell subset to be responsible to phagocytosis by macrophages.

As a developmental method for immunopotentiation therapy of leprosy, the introduction of recent advance in cancer field was firstly associated. However, we presumed in the same time the following pharmacological characteristics to be the indispensable requirements for an immunopotentiative substance suitable to the treatment of leprosy: 1 . excellent whole body distribution and intracellular infiltration, 2. excellent long-activity, and 3. low toxicity, and 4. mild action on host. Especially thinking about 4, we were interested in plant source polysaccharides. One of authors informed us of a marked decrease of ascite by cancer patients after oral use of a crude extract prepared from bamboo grass. As for the crude extract of bamboo grass, Kuroki, et $a l .^{3)}$ and Sakai, et al. ${ }^{4)}$ reported the effect on experimental cancer. However, since the extraction method was so simple that a criticism was also proposed $^{5)}$. While, Uchiyama, et $a l^{6}{ }^{6}$ examined the purification and the analysis of polysaccharides contained in Yakushima-bamboo. However, afterwards, no report regarding either chemical or anticancer studies on bamboo grass could be searched out. In this paper, as the first step, the results of analyzing the components in bamboo grass are reported.

\section{Experimental Methods}

1. Materials: Bamboo grass was get from kiikuniya Yakkyoku Co. already sliced and dried after collected from the foot of Mount Akagi. 


\section{Extraction of bamboo grass:}

a) The dried slices $(500 \mathrm{~g})$ were put into a bamboo crate $($ dial $30 \mathrm{~cm}$, depth $40 \mathrm{~cm})$. It was soaked in 101 of $0.1 \% \mathrm{Ca}(\mathrm{OH})_{2}{ }^{3)}$ inside 201 enameled bath and boiled for $2 \mathrm{hrs}$. With the progress of extraction, the $\mathrm{pH}$ of extract gradually changed to neutral. It was always preserved in basic side by occasional addition of small amount of $\mathrm{Ca}(\mathrm{OH})_{2}$ powder. The extraction was repeated 4 times. The $\mathrm{pH}$ of pooled extract was adjusted to 11.0 with $60 \% \mathrm{AcOH}$. The extract was once filtered through threefold gauzes and again adjusted to $\mathrm{pH}$ 8.0. It was deproteinized by Sevag method and separated aqueous layer was treated with activated charcoal and filtered. The filtrate was condensed to about 21 below $60^{\circ} \mathrm{C}$ under reduced pressure. During the condensation, the correction of $\mathrm{pH}$ by $\mathrm{Ca}(\mathrm{OH})_{2}$ powder was again needed. The condensate was dialyzed through Visking Tubing $36 / 32(\mathrm{~cm})$ against tapped deionized water over night and lastly lyophilized. Japan BCG Laboratory once kindly helped the lyophilization of large volume extract. The yield was $730 \mathrm{~g}$ from $20 \mathrm{~kg}$ of slices. The residue was greenish brown colored powder and was relish when dissolved in water.

The lyophilized powder without foregoing deproteinization was highly hygroscopic. Therefore, always, the lyophilized powder after deproteinized was used. This powder was named as crude powder.

b) One $\mathrm{kg}$ of slices was soaked over-night in 21 of cold $0.2 \mathrm{~N} \mathrm{NaOH}$. The extract was treated similarly to the case (a) and the separated aqueous layer after deproteinized by Sevag method was condensed by Thin Channel TCIR (Amicon Far East Ltd.) set in cold room to fractionate polysaccharides into (A) M. W. above $5 \times 10^{4}$ and (B) M. W. $10^{3}-5 \times 10^{4}$. No change of $\mathrm{pH}$ to acidic side could be observed during the circulatory condensation by the Thin Channel in cold room. The fractions $\mathrm{A}$ and $\mathrm{B}$ were separately dialyzed against deionized water repeatedly inside the Thin Channel. Lastly, they were lyophilized and the residues were named as powders $\mathrm{A}$ and $\mathrm{B}$ respectively. Powder $\mathrm{A}$ : brownish green light powdre, yield $20.8 \mathrm{~g}$ from $1 \mathrm{~kg}$ slices. Powder B : brown powder, yield $56.9 \mathrm{~g}$. In some cases, powder A or $\mathrm{B}$ was further dialyzed against deionized water.

3. Fractionation of polysaccharides: The crude powder was fractionated either by a DEAE-cellulose column (DE 23, Whatman ; Column size $30 \times 300 \mathrm{~mm}$ ) according to Uchiyama, et $a{ }^{6}{ }^{6}$ or by a Sephadex G-100 column (Particle size fine, Pharmacia Uppsala; Column size $52 \times 400 \mathrm{~mm}$ ) according to the method of Andrews ${ }^{7}$. The powders $A$ and $B$ were in some cases further purified through a Sephadex G-25 column (Particle size medium, Pharmacia Uppsala ; Column size $30 \times 300 \mathrm{~mm}$ ) developing with $0.01 \mathrm{M}$ phosphate, $\mathrm{pH} 7.8$. The fractions purified through DEAE-cellulose column were occasionally condensed by Immersible Molecular Separator Kit (Millipore Corp.). Amicon B15 Ultrafiltration Kit was also used for condensation of small volume specimens.

4. Colorimetric methods: Polysaccharides were measured by phenol sulfuric acid ${ }^{8}$. Sulfate was measured by benzidine method ${ }^{9)}$ after hydrolysis at $85-90^{\circ} \mathrm{C}$ for $30-36$ hrs. with $25 \%$ formic acid in sealed glass tube. Phosphate was measured by Fiske-Subbarow reagent after hydrolysis at $85-90^{\circ} \mathrm{C}$ for $24 \mathrm{hrs}$. with $5 \%$ TCA in sealed glass tube. 
5. Gas chromatography $(G C)$ of monosaccharides: Polysaccharides or the standard hexoses and pentoses were heated at $70^{\circ} \mathrm{C}$ for $16 \mathrm{hrs}$, with $3 \% \mathrm{MeOH}-\mathrm{HCl}$ in sealed glass tube ${ }^{10 !}$. The solvent was completely evaporated below $40^{\circ} \mathrm{C}$ and the residue was measured by the method of Yamakawa, et al. ${ }^{11}$ as TMS esters of monosaccharides. Apparatus: Shimadzu 4-CM, FID; Column : glass column, $4 \times 2000 \mathrm{~mm}$ packed with $1.5 \%$ SE-52 on chromosorb W ; Program : $125-238^{\circ} \mathrm{C}, 2^{\circ} \mathrm{C} / \mathrm{min}$, detector $250^{\circ} \mathrm{C}, \mathrm{N}_{2} 40 \mathrm{ml} / \mathrm{min} ., \mathrm{H}_{2} 0.65 \mathrm{~kg}$, air $1.0 \mathrm{~kg}$.

6. Analysis of amino acid components of protein: The greenish Precipitate of protein isolated by Sevag method was dried and hydrolyzed at $100^{\circ} \mathrm{C}$ for 24 hrs. with $6 \mathrm{~N} \mathrm{HCl}$ in sealed glass tube. It was dried in vacuo and made slightly alkaline with $0.05 \mathrm{~N} \mathrm{NH}_{4} \mathrm{OH}$ and again dried below $50^{\circ} \mathrm{C}$. The residue was analyzed by Hitachi KLA-5 amino acid analyzer. Neutral and acidic amino acids: Hitachi Custom 2611, Column $6 \times 550 \mathrm{~mm}, 0.2 \mathrm{~N}$ citrate, $\mathrm{pH} 3.25$ (valine, $\mathrm{pH}$ 4.15); Basic amino acids: Hitachi Custom 2613, Column $6 \times$ $100 \mathrm{~mm}, 0.35 \mathrm{~N}$ citrate, $\mathrm{pH} 5.28$; Measuring: heated at $100^{\circ} \mathrm{C}$ with ninhydrin, at $470 \mathrm{~nm}$ (proline, at $440 \mathrm{~nm}$ ), Chart $3 \mathrm{~mm} / \mathrm{min}$.

Prior to the measuring by amino acid analyzer, the components were examined by thin layer chromatography developing with $\mathrm{n}-\mathrm{BuOH}-\mathrm{AcOH}-\mathrm{H}_{2} \mathrm{O}(3: 1: 1)$ as the first system and phenol- $\mathrm{H}_{2} \mathrm{O}(3: 1)$ or phenol- $0.08 \% \mathrm{NH}_{4} \mathrm{OH}(4: 1)$ as the second one. The gas chromatographic analysis of amino acids by derivating to dimethylformamide dialkylacetal esters (DMFDAA, alkyl: $\mathrm{Me}$ or $\mathrm{n}-\mathrm{Bu}$, Tokyo Kasei Kogyo Co.) was also examined by Shimadzu 4-CM through glass column $(4 \times 1000 \mathrm{~mm})$ packed by $1 \%$ OV -17 on chromosorb $W$. The program was set at $80^{\circ} \mathrm{C}$ for 5 mins., $80-280^{\circ} \mathrm{C}$ by $4{ }^{\circ} \mathrm{C} / \mathrm{min}$. under preservation of detector temperature at $300^{\circ} \mathrm{C}$ and a gaseous condition $\left(\mathrm{N}_{2} 40 \mathrm{ml} / \mathrm{min}\right.$., $\mathrm{H}_{2} 0.65 \mathrm{~kg}$. air $\left.1.0 \mathrm{~kg}\right)$. However, since both of separating leucine-isoleucine and measuring reliably of amino acids having retention times longer than that of lysine (alkyl of DMFDAA: Me) or phenylalanine (alkyl of DMFDAA : $\mathbf{n}-\mathrm{Bu}$ ) were insufficient in addition to a deficiency in this method that oxyamino acids can not be analyzed by these derivatizations, the measuring by GC was stopped.

7. Analysis of alkalies: All the glass vessels were cleansed 2 times with boiling distilled water each for $1 \mathrm{hr}$. Ten grams of dried slices were percolated or extracted 2 times with $150 \mathrm{ml}$ each of cold or boiled distilled water respectively. The same amount of slices were also extracted 2 times with $150 \mathrm{ml}$ each of boiling $0.1 \% \mathrm{Ca}(\mathrm{OH})_{2}$ for $2 \mathrm{hrs}$. each. They were filtered through the well-washed filter papers (Toyo Roshi No. 2), condensed below $80^{\circ} \mathrm{C}$ under reduced pressure, and were adjusted the volumes to about $0.2 \mathrm{~g}$ of slices per $1 \mathrm{ml}$ of extracts. Some portions of them were further fractionated by dialysis through Visking Tubings $20 / 32(\mathrm{~cm})$ according to Table 4 , which were beforehand well washed by repeated soakages to distilled water. To the total volume of each extract, $3 \mathrm{ml}$ of $\mathrm{HCl}$ and $2 \mathrm{ml}$ of $\mathrm{H}_{2} \mathrm{O}$ were added and evaporated to dryness on a steam bath. One $\mathrm{ml}$ of $\mathrm{HCl}$ and $7 \mathrm{ml}$ of $\mathrm{H}_{2} \mathrm{O}$ were added to the residue and the solution was again filtered. The alkalies in the filtrate were measured by Hiranuma Flame Photometer FPF-2A under the use of filter $589 \mathrm{~nm}$ (for $\mathrm{Na}$ ) or $768 \mathrm{~nm}$ (for $\mathrm{K}$ ) and gaseous pressures of propane, $0.1 \mathrm{~kg} / \mathrm{cm}^{2}$ and air, $1.8 \mathrm{~kg} / \mathrm{cm}^{2}$. On the other side, about $1 \mathrm{~g}$ of slices was incinerated inside a porcelain crucible at $550^{\circ} \mathrm{C}$ 
for $12 \mathrm{hrs}$. by an electric furnace. Three $\mathrm{ml}$ of $\mathrm{HCl}$ and $2 \mathrm{ml}$ of $\mathrm{H}_{2} \mathrm{O}$ were added to the residue and evaporated to dryness on the steam bath. To the residue, $1 \mathrm{ml}$ of $\mathrm{HCl}$ and $5 \mathrm{ml}$ of $\mathrm{H}_{2} \mathrm{O}$ were added and the solution volume was adjusted to $20 \mathrm{ml}$ with $\mathrm{H}_{2} \mathrm{O}$. It was filtered and measured the alkalies similarly.

\section{Results and Discussion}

1. Carbohydrates: The fractionation through DEAE-cellulose column clearly separated fractions $1-4$ as shown in Table 1 , where the acidity increases from fraction 1 to fraction 4 .

Table 1 Polysaccharides Separated by Fractionation of $1 \mathrm{~g}$ Crude Powder through DEAEcellulose Column

\begin{tabular}{|c|c|c|c|c|c|c|}
\hline Fraction & $\begin{array}{c}\text { Developing } \\
\text { system }\end{array}$ & $\begin{array}{c}\text { Elution } \\
\text { volume (ml) }\end{array}$ & $\begin{array}{l}\text { Yield }(\mathrm{mg}) \text { after } \\
\text { lyophilization }\end{array}$ & Appearance & $\begin{array}{l}\text { Solubility } \\
\text { in water }\end{array}$ & $\begin{array}{l}\text { Content }(\%) \text { of } \\
\text { polysaccharides }\end{array}$ \\
\hline 1 & $\mathrm{H}_{2} \mathrm{O}$ & $60-150$ & 57.1 & $\begin{array}{l}\text { slightly greenish } \\
\text { powder }\end{array}$ & high & 91.9 \\
\hline 2 & $\begin{array}{c}0.2 \mathrm{M} \\
\mathrm{NaOAc}\end{array}$ & $255-285$ & 65.0 & $\begin{array}{l}\text { slightly yellow- } \\
\text { ish green } \\
\text { powder }\end{array}$ & high & 89.8 \\
\hline 3 & $\begin{array}{l}0.2-1.0 \mathrm{M} \\
\mathrm{NaOAc}\end{array}$ & $400-455$ & $\ldots \ldots * 2$ & $\begin{array}{l}\text { yellowish brown } \\
\text { powder }\end{array}$ & $\ldots$ & $10.1^{* 3}$ \\
\hline 4 & $1 \mathrm{~N} \mathrm{NaOH}$ & $495-545$ & 69.1 & $\begin{array}{l}\text { dark brown } \\
\text { powder }\end{array}$ & $\begin{array}{c}\text { somewhat } \\
\text { low }\end{array}$ & 89.3 \\
\hline $\mathrm{PUL}^{* 4}$ & $\ldots$ & $\ldots$ & 219.0 & $\begin{array}{l}\text { dark brown } \\
\text { solution }\end{array}$ & $\cdots$ & \\
\hline
\end{tabular}

*1 Measured as pentose by phenol sulfuric acid

*2 Since the content of polysaccharides was presumed to be low, it was examined as solution alone.

*3 $\mathrm{mg} /$ total volume of fraction 3

*4 Each fraction was condensed to small volume by ultrafiltration through Visking Tubing $8 / 32$ $(\mathrm{cm}$, dial $6 \mathrm{~mm})$. It was dialyzed against tapped deionized water over night and lyophilized. The ultrafiltrable layers of fractions 1-4 were pooled.

By the use of this fractionation method, the contents of polysaccharides were found to be high throughout all the fractions 1-4. The free monosaccharides and those as the components of polysaccharides contained in each of fractions 1-4 are summarized in Table 2(a) and (b) respectively. Both of ribose and mannose which were found to be as free monosaccharides of low contents could not be detected throughout the hydrolyzates of fractions 1-4. The ratios of ribose/mannose were about $8: 6-7: 5$ in all of fractions 1,3 and an ultrafiltrable layer pooled from fractions 1-4. It was presumed that both of ribose and mannose can not be incorporated into polysaccharides by the biosynthesis in vivo. Uchiyama, et al. ${ }^{6}$ had already reported the contents of arabinose, xylose, galactose, and glucose to be the components of polysaccharides in fractions 1 and 2 or their subfractions. The presence of these monosaccharides as the components was again certified by our GC analysis. However, in addition to their precise result, it was found that the content of glucose increases from fraction 1 to fraction 4, especially to the pooled ultrafiltrable layer (PUL) while the contents of pentoses seem to decrease from fraction 1 to fraction 4 . In addition, the ratio of xylose/- 
Table 2 Contents of Free Monosaccharides (a) and Monosaccharide Components of Polysaccharides (b) in Fractions separated through DEAE-cellulose Column, Measured by Gas Chromatography

(a)

(b)

\begin{tabular}{|c|c|c|c|c|c|c|c|c|c|c|}
\hline Fraction & $\begin{array}{c}\text { Ribose } \\
(\mu \mathrm{g})\end{array}$ & $\begin{array}{c}\text { Content } \\
(\%)\end{array}$ & $\underset{(\mu \mathrm{g})}{\operatorname{Mannose}}$ & $\begin{array}{c}\text { Content } \\
(\%)\end{array}$ & $\begin{array}{l}\mu \mathrm{g} \text { put } \\
\text { into } \\
\text { column }\end{array}$ & Fraction & $\underset{(\%)}{\text { Arabinose }}$ & $\begin{array}{c}\text { Xylose } \\
(\%)\end{array}$ & $\underset{(5)}{\text { Galactose }}$ & $\begin{array}{c}\text { Glucose } \\
(\%)\end{array}$ \\
\hline 1 & 0.85 & 4.25 & 0.58 & 2.90 & 20 & 1 & 35 & 45 & 19 & trace \\
\hline 2 & $\ldots$ & $\ldots$ & $\ldots$ & $\ldots$ & 20 & 2 & 50 & 31 & 18 & trace \\
\hline 3 & 0.85 & 4.25 & 0.54 & 2.70 & 20 & 3 & 28 & 46 & 20 & 4 \\
\hline 4 & $\ldots$ & $\ldots$ & $\ldots$ & $\ldots$ & 20 & 4 & 24 & 47 & $\ldots$ & 29 \\
\hline PUL* & 0.76 & 0.15 & 0.55 & 0.11 & 500 & PUL* & 14 & 18 & 23 & 44 \\
\hline
\end{tabular}

* pooled ultrafiltrable layer of fractions $1-4$ Attenuation : $8 \times 10^{2}$ (a) and $8-16 \times 10^{2}$ by $2-4 \mu \mathrm{g}$ (b)

glucose in the pooled ultrafiltrable layer was found to be markedly lower than those in fractions $1-4$.

Another result indicated that when crude powder or fractions 2-4 were separately developed through Sephadex G-100 column, as shown in Fig. 1., the ratio of optical density at $490 \mathrm{~nm}$ (hexose peak) divided by that at $480 \mathrm{~nm}$ (pentose peak) at a optical peak of molecular filtration pattern gradually increased with the increase of elution volume. Both of these results suggested that glucose content increases with the increase in acidities of polysaccharides and also with the decrease in molecular weights of polysaccharides.

Every optical peak of saccharides examined by phenol sulfuric acid was measured both at $490 \mathrm{~nm}$ (hexose peak) and at $480 \mathrm{~nm}$ (pentose peak, dotted line). The numerical on an optical peak is the number of fraction obtained by fractionation through DEAEcellulose column, in which the same optical peak was found. Net volume of column : $830 \mathrm{ml}$. Human IgG (Nutrit. Biochem. Coop.) was once purified through DEAE-cellulose.

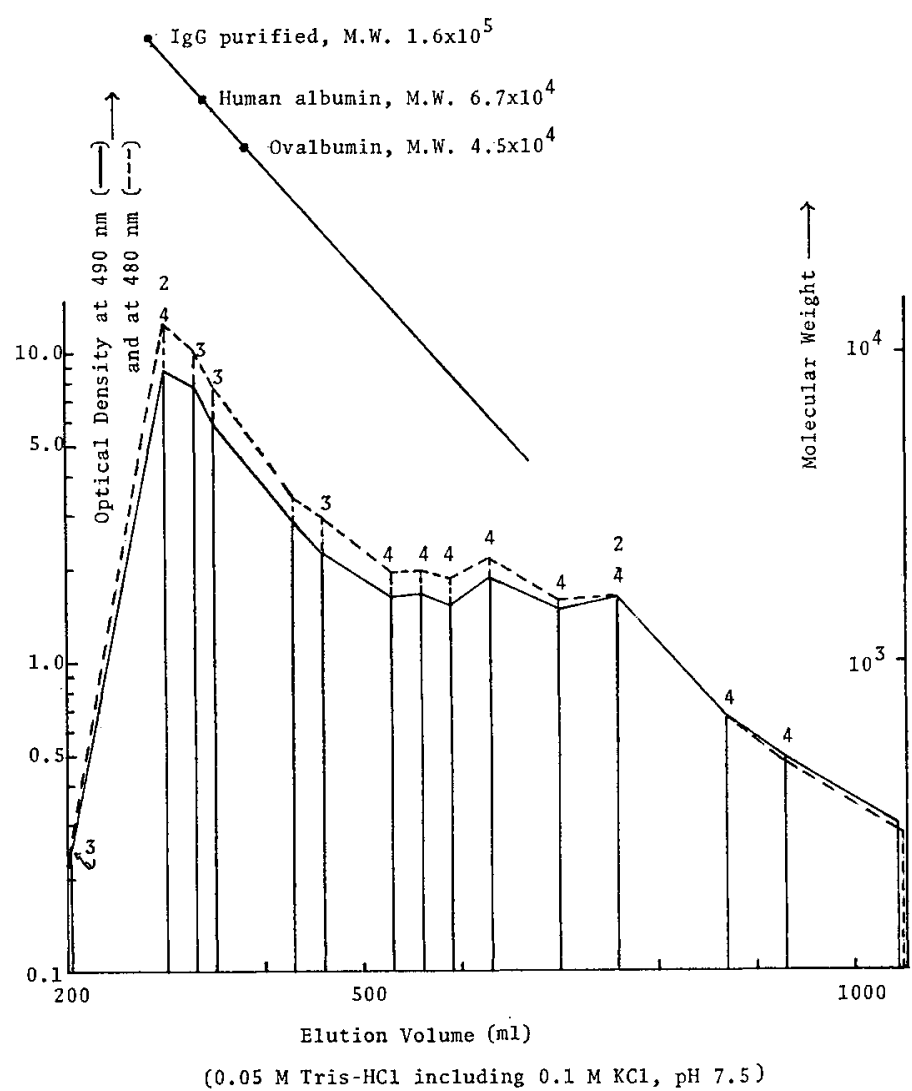

Fig. 1 Molecular Filtration of Crude Powder or Fractions 1-4 Obtained by DEAE-collulose Column Fractionation 
However, a serious deficient point of GC analysis after acidic hydrolysis according to the report by Hirase, et al. ${ }^{10)}$ where they analyzed the polysaccharides of $\mathrm{PSK}^{12,13)}$ was that the detection of a subpeak separated from the main peak was usual. In this report, the main and subpeaks of a monosaccharide were summed up by measuring the weight of transcribed alumi foil. Recently, Honda, et al. ${ }^{14)}$ reported a favorable dithioacetal method capable of avoiding this difficulty.

2.Conjugated sulfate: During the condensation of $\mathrm{Ca}(\mathrm{OH})_{2}$ extract to obtain crude powder under warming below $60^{\circ} \mathrm{C}$, the $\mathrm{pH}$ of the extract gradually changed to acidic side thus it needed the correction of $\mathrm{pH}$. However, since this phenomenon could not be found throughout the condensation by Thin Channel without warming, we presumed the possible presence of sulfate conjugated to polysaccharides and unstable by warming. Really, we detected a serious positivity by benzidine reaction when measured crude extract, fractions $1-4$ or the pooled ultrafiltrable layer. However, since it was experienced that the benzidine reaction itself can be influenced by anionic ions such as phosphate which derived from the medium of a case, it was examined after exhaustive dialysis to eliminate anionic ions. One gram of powder A or B obtained by Thin Channel fractionation was dissolved in $20 \mathrm{ml}$ of distilled water and dialyzed for 24 hours against tapped deionized water. It was once lyophilized and dissolved in $25 \mathrm{ml}$ of 3 fold diluted formic acid. After centrifugation at $7000 \mathrm{rpm}$ for 10 minutes, a portion $(10 \mathrm{ml})$ of the supernatant was hydrolyzed and the content of sulfate in the hydrolyzate was compared with that in original solution. In the case of powder A (M. W. above $\left.5 \times 10^{4}\right)$, the centrifugation was once repeated after the hydrolysis to eliminate newly produced precipitate. The result was as follows.

$$
\begin{array}{ccc}
\multicolumn{2}{c}{\text { before hydrolysis }} & \text { after hydrolysis } \\
\text { powder A } & 227.8 \pm 34.4 \mu \mathrm{g} / \mathrm{g}, & 634.7 \pm 157.3 \mu \mathrm{g} / \mathrm{g} \\
\text { powder B } & 26.9 \pm 7.7 \mu \mathrm{g} / \mathrm{g} & 219.0 \pm 49.4 \mu \mathrm{g} / \mathrm{g}
\end{array}
$$

The sulfate contents in powders $A$ and $B$ are the averages of 13 and

8 specimens respectively.

The result still suggested the presence of very low content of conjugated sulfate, especially in low molecular fraction, powder B. As shown in Fig. 1, the fraction 4 whose acidity was strongest among fractions 1-4 included high contents of low molecular polysaccharides. In addition, as shown in Table 2, glucose contents of fraction 4 and PUL were much higher than the other fractions. Therefore, at first, we imagined the possible presence of an acidic polysaccharide conjugating glucose sulfate. Although it could not be elucidated yet whether the $\mathrm{pH}$ change to acidic side during condensation under warming was caused by the sulfate freed from such a polysaccharide or not, still it remains the possible isolation of an acidic radical during the condensation.

3. Conjugated phosphate: None of conjugated phosphate could be found in all of crude powder and fractions $1-4$.

4. Amino acid composition of protein: The two dimensional development of hydrolyzate from $5 \mathrm{mg}$ protein as $5 \mu \mathrm{l}$ solution on a silica gel plate (DC-Plastikfolien, Merck) detected the 
Table 3 Amino Acid Composition of Bamboo Grass Protein Shown as Molecular Per Cent

\begin{tabular}{llllll}
\hline \hline basic amino acids & \multicolumn{4}{c}{ neutral and acidic amino acids } \\
\hline lysine & 4.33 & aspartic acid & 11.78 & valine & 5.78 \\
histidine & 0.94 & threonine & 4.78 & methionine & 2.61 \\
arginine & 2.47 & serine & 6.07 & isoleucine & 5.94 \\
& & glutamic acid & 12.13 & leucine & 7.73 \\
& & proline & 6.66 & tyrosine & 2.28 \\
& & glycine & 9.47 & phenylalanine & 4.05 \\
& & alanine & 13.01 & & \\
\hline
\end{tabular}

presence of all amino acids other than histidine, arginine, threonine, and phenylalanine which were firstly found by amino acid analyzer as shown in Table 3. However, when a solution of bamboo grass protein dissolved in $0.1 \% \mathrm{NaHCO}_{3}$ was analyzed by a recording spectrophotometer (Hitachi EPS 3T), the protein peak at $280 \mathrm{~nm}$ could not be detected even at the concentration of $200 \mu \mathrm{g} / \mathrm{ml}$. At present stage, the question whether the protein is conjugable to acidic polysaccharides of bamboo grass can not be elucidated.

5. Alkalies: The result of flame photometric analysis of alkalies is shown in Table 4. The high content of potassium was notable. The relation between the high content and a possible diuretic action to be a cause of decreasing ascite of cancer patients is interesing.

The difficult problem by examining the efficacy of plant source polysaccharides is the condensation or isolation of an essentially effective substance. For example, both of $\mathrm{ATSO}^{15}$ as a condensate of polysaccharides and Ceriolin $\mathrm{B}^{16)}$ as a hopeful substance in the filtrate were found in PSK. Although a possible decomposition of bamboo grass polysaccharides may be avoided by the extraction without warming, the extraction by sodium hydroxide before fractionation

Table 4 Alkalies in Bamboo Grass Measured Flame Photometrically

\begin{tabular}{|c|c|c|c|}
\hline & & $\mathrm{Na}$ & $\mathrm{K}$ \\
\hline 1 . & whole leaves & $0.19^{*}$ & $8.53^{*}$ \\
\hline 2. & $\begin{array}{l}\text { percolate } 2 \text { times extracted } \\
\text { at room temperature, } \\
\text { each for } 24 \text { hours }\end{array}$ & 0.08 & 1.00 \\
\hline 3. & $\begin{array}{l}\text { after dialysis of } \\
2 . \text { for } 24 \text { hours }\end{array}$ & 0.015 & 0.008 \\
\hline 4. & $\begin{array}{c}\text { extract of residue } 2 ., \\
2 \text { times by boiling water } \\
\text { each for } 6 \text { hours }\end{array}$ & 0.005 & 1.81 \\
\hline 5. & $\begin{array}{l}\text { after dialysis of } \\
\text { 4. for } 24 \text { hours }\end{array}$ & 0.006 & 0.006 \\
\hline 6. & $\begin{array}{l}\text { extract of residue } 4 ., \\
2 \text { times by hot } \mathrm{Ca}(\mathrm{OH})_{2}, \\
\text { followed by dialysis } \\
\text { for } 24 \text { hours }\end{array}$ & 0.03 & 0.013 \\
\hline
\end{tabular}

* mg alkalies/g of leaves Dialysis: always against tapped deionized water

by Thin Channel brought about a serious contamination of various components especially into extract $\mathrm{A}$ of higher molecular weight. Thus, the contents of polysaccharides in powders $\mathrm{A}$ and $\mathrm{B}$ measured as pentose were found to be only $12.6 \%$ and $37.5 \%$ respectively. Therefore, even though a dose is strictly based on the contents of polysaccharides, the evaluation of biological activities of polysaccharides contained in powders $\mathrm{A}$ and $\mathrm{B}$ will become difficult problem. However, since the possible heat decomposition of polysaccharide which is pre- 
sumed to be an essentially effective component is supposed to be undesirable for examing the efficacy of naturally growing bamboo grass, the question whether the extract of bamboo grass is immunopotentiative or not will be examined in the near future by the use of powders A and $\mathrm{B}$.

\section{Summary}

Since plant source polysaccharides were presumed to be immunopotentiative substances and suitable to the treatment of leprosy by their mild effect on host, at the first step, the analytical studies on the components of bamboo grass were performed. The results found were as follows:

1. Some extraction methods of bamboo grass were examined and compared.

2. The monosaccharide components of acidic polysaccharides were equal to those found by Uchiyama, et al. using DEAE-cellulose column. However, the content of glucose was found to be highest in strongly acidic fraction and also presumed to be higher in lower molecular weight fractions. While, the contents of pentoses seemed to be contrary to the tendency of glucose content.

3. Besides monosaccharides of carbohydrates, ribose and mannose were slightly detectable as free monosaccharides.

4. The presence of small amount of conjugated sulfate could be presumed.

5. Conjugated phosphate could not be detected.

6. The amino acid composition of protein obtained by Sevag method was analyzed.

7. Alkalies of bamboo grass were measured and a high content of potassium was noticed.

\section{Acknowledgements}

The authors wish to thank Japan BCG Laboratory, concerning the lyophilization of large amount of crude extract. They are also indebted to Dr. M. Suzuki of Department of Pharmaceutical Sciences, Science University of Tokyo for the analysis of amino acids bp analyzer.

\section{References}

1) M. Gidoh, S. Tsutsumi, M. Narita and K. Fukushi: Influences of several antileprosy drugs on immunological state of experimental animals. Jap. J. Leprosy, 48, 159-169 (1979).

2) T. J. Birdi, P. R. Salgame and N. H. Antia: The role of macrophages in leprosy as studied by protein synthesis of macrophages from resistant and susceptible hosts, a mouse and human study. Leprosy in India, 51, 23-42 (1979).

3) M. Kuroki, G. Fukuzawa and K. Yoshimura: Studies on antitumor substance obtained from alkaline extract of Sasa-leaves. IV. Saccharides as antitumor agent and their effectiveness. Annual Reports of Nasu Res. Lab., 5, 40-43 (1967).

4) S. Sakai, G. Saito, J. Sugiyama, T. Kamasuka, S. Takeda and T. Takano: Anticancer effect of polysaccharide fraction prepared from Bamboo grass. Gann, 55, 197-203 (1964).

5) H. von Osswald und D. Schmähl: Über die Unwirksamkeit der Bamfolin-Charge Y 40 1256,8 an experimentellen Tumoren: Arzneimittelforsch., 18, 497-498 (1968).

6) S. Suzuki, T. Saito, M. Uchiyama and S. Akiya: Studies on the anti-tumor activity of polysaccharides. I. Isolation of hemicelluloses from Yakushima-bamboo and their growth inhibitory activities against Sarcoma-180 solid tumor. Chem. Pharm. Bull., 16, 2032-2039 (1968).

7) P. Andrews: Estimation of the molecular weights of proteins by Sephadex gel filtration. Biochem. 
J., 91, 222-233 (1964).

8) J. E. Hodge and B. T. Hofreiter: Determination of reducing sugars and carbohydrates. Methods in Carbohydrate Chemistry, 1, 388-389. R. L. Whistler and M. I. Wolfrom (eds), Academic Press Inc., New York, N. Y., (1962).

9) C. A. Antonopoulos: Modification and determination of sulfate in mucopolysaccharides by the benzidine method. Acta. Chem. Scand., 16, 1521-1522 (1962).

10) S. Hirase, Y. Nakai, T. Akatsu, A. Kobayashi, M. Ohara, K. Matsunaga, M. Fujii, T. Kodaira, T. Fujii, T. Furusho, Y. Ohmura, T. Wada, C, Yoshikumi, S. Ueno and S. Ohtsuka: Structural studies on the anti-tumor active polysaccharides from Coriolus vesicolor (Basidiomycetes). Yakugaku Zasshi, 96, 413-418 (1976).

11) T. Yamakawa and N. Ueta: Gas-liquid chromatography of carbohydrates. Jap. J. Exptl. Med., 34, 37-51 (1964).

12) S. Tsukagoshi: Host-mediated antitumor activity of polysaccharides, with special reference to the effect of PSK. A protein bound polysaccharide isolated from Basidiomycetes. Cancer and Chemotherapy, 1, 251-257 (1974).

13) H. Maebashi, H. Kurahashi, T. Hattori and F. Hirose: On the general pharmacological action of a protein bound polysaccharide, PS-K isolated from Basidiomycetes. Kiso to Rinshö, 9, 1515-1526 (1975).

14) S. Honda and K. Kakehi: On the development of dithioacetal method fot analyzing monosaccharide composition of carbohydrate and the products after its hydrolysis by oxidation with periodic acid, and the application of the method for analyzing saccharide chain. The 2nd Symposium on Carbohydrate Chemistry, p. 30-31 (1979).

15) K. Fujii, H. Ito, and S. Naruse: Studies on antitumor activities of Basidiomycetes. Antitumor activity of a polysaccharide produced by a strain of Coriolus versicolor Fries. Folia pharmacol. japon., 70, 571-577 (1974).

16) T. Takeuchi, S. Takahashi, H. Iinuma and H. Umezawa: Diketocoriolin B, an active derivative of ceriolin B produced by Coriolus consors. J. Antibiotics, 26, 631-635 (1971).

\section{らい治療のための免疫賦活物質探索に関する研究}

\section{（I）く交ざさの分析学的研究}

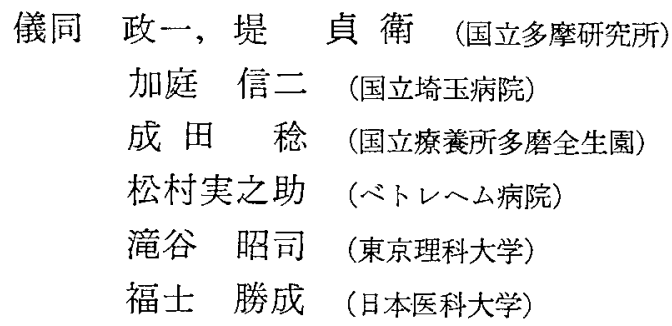

化学療法と併用される免疫賦活療法はらい治療の有力 な手段と考えられる。植物由来多糖体に優秀な細胞内浸 透性や宿主への緩和な作用が望見され，著者らの一人は くまざさ抽出物服用により癌患者腹水が著減したという 臨床経験を提起したので，その免疫賦活作用の有無を調 ぶる前に成分分折を施行した。熱時または冷時に乾燥葉 細切片を抽出し，イオン交换クロマトグラフィー, 分子 穊過, 種々の限外滤過で酸性あるいは分子量の違いによ り数種分画に别けた。ガスクロマトグラフィーで，内山 らの報告同様多糖構成単糖として溜出の速い万加らラ ビノーズ，キシローズ，ガラクトーズ，グルコーズを検 出し, 新知見としてグルコーズは強酸性低分子分画に多

く, 一方五炭裙は逆に少ない傾向を認め, また多糖に取 込まれない遊離単糖としてリボーズ，マンノーズの微量 を検出した。抽出液の加温濃縮時に $\mathrm{pH}$ が酸性一と変化 しがちであるのに冷時濃縮ではこの現象が見られないの で, 結合硫酸基の存在と加温時遊離を想定し調べたとこ ろ, 微量の結合硫酸基の存在を推定したが，それが酸性 へと傾く原因か，その結合相手が果して糖か否かは明ら かでない。結合性燐酸は認められなかった。蛋白構成了 ミノ酸として 16 種アミノ酸の構成比が 算出された。し かしその糖との結合は明らかでない。炎光分析で著量の カリウムが含まれている事が認められたが，抽出率は低 かった。利尿作用との関係が興味深い。 